\title{
Effects of Pyridoxine on Selected Appetite Regulating Peptides mRNA Expression in Hypothalamic PVN/ARC Nuclei and Gastrointestinal Tract Tissues
}

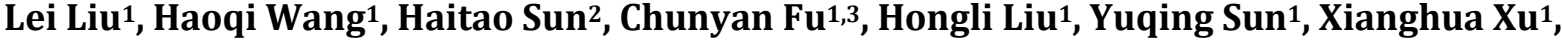 \\ Weiji Chen ${ }^{1}$, Wenqiang $\mathrm{Wu}^{1}$, Fuchang $\mathrm{Li}^{{ }^{*}}$

\begin{abstract}
${ }^{1}$ Shandong Provincial Key Laboratory of Animal Biotechnology and Disease Control and Prevention, Department of Animal Science and Technology, Shandong Agricultural University, Taian, China

${ }^{2}$ Animal Husbandry and Veterinary Institute, Shandong Academy of Agricultural Sciences, Jinan, China

${ }^{3}$ Poultry Institute, Shandong Academy of Agricultural Sciences, Jinan, China
\end{abstract} \\ Email: *chlf@sdau.edu.cn
}

How to cite this paper: Liu, L., Wang, H.Q., Sun, H.T., Fu, C.Y., Liu, H.L., Sun, Y.Q., Xu, X.H., Chen, W.J., Wu, W.Q. and Li, F.C. (2017) Effects of Pyridoxine on Selected Appetite Regulating Peptides mRNA Expression in Hypothalamic PVN/ARC Nuclei and Gastrointestinal Tract Tissues. Advances in Bioscience and Biotechnology, 8, 273-282.

https://doi.org/10.4236/abb.2017.89020

Received: July 1, 2017

Accepted: September 10, 2017

Published: September 13, 2017

Copyright (c) 2017 by authors and Scientific Research Publishing Inc. This work is licensed under the Creative Commons Attribution International License (CC BY 4.0).

http://creativecommons.org/licenses/by/4.0/ (c) (i) Open Access

\begin{abstract}
An experiment was conducted to investigate the effect of dietary pyridoxine on the gene expression of appetite-regulating peptides in the hypothalamus and gastrointestinal tract of rabbits. Thirty-two rabbits were randomly divided into 2 treatments for 8 weeks ( 16 replicates/group and 1 rabbit/replicate). The treatments were fed a basal diet (control, measured pyridoxine content is 4.51 $\mathrm{mg} / \mathrm{kg}$ ) and the basal diet with a pyridoxine supplementation at $10 \mathrm{mg} / \mathrm{kg}$ (pyridoxine, measured pyridoxine content is $14.64 \mathrm{mg} / \mathrm{kg}$ ). The results showed that dietary pyridoxine did not significantly alter the mRNA levels of neuropeptide $\mathrm{Y}$, agouti related peptide, pro-opiomelanocortin and cocaine, amphetamine regulated transcript, peptide YY and cholecystokinin in arcuate nucleus, peptide YY in jejunum and ileum, and cholecystokinin in duodenum, jejunum and ileum $(P>0.05)$. Compared with the control, the mRNA levels of corticotropin-releasing hormone and melanocortin 4 receptor in paraventricular nuclei and peptide YY in duodenum were significantly decreased after pyridoxine treatment $(P<0.05)$. In conclusion, the appetite genes of melanocortin 4 receptor and corticotropin-releasing hormone in paraventricular nuclei and peptide YY in duodenum are involved in the pyridoxine-caused hyperphagia.
\end{abstract}

\section{Keywords}

Pyridoxine, Brain-Gut Peptides, Appetite Control 


\section{Introduction}

The hypothalamus is a crucial region for integrating signal from central and peripheral pathways and plays a major role in appetite regulation. In the arcuate nucleus (ARC) of hypothalamus, there are 2 major neuronal populations, which influence energy homeostasis. One neuronal circuit inhibits food intake, via the expression of the pro-opiomelanocortin (POMC) and cocaine and amphetamine regulated transcript (CART) [1] [2]. The other neuronal circuit stimulates food intake, via the expression of neuropeptide $\mathrm{Y}(N P Y)$ and agouti related peptide $(A g R P)$ [3]. The $N P Y / A g R P$ and $P O M C / C A R T$ neurones perform a primary sensory function in the neural regulation of appetite. These "first order" neurones then relay metabolic information to other "second order" neuronal populations located elsewhere in the hypothalamus such as the corticotropin-releasing hormone $(C R H)$ and melanocortin 4 receptor $(M C 4 R)$ in the paraventricular nuclei (PVN) [4].

Gut hormones act to modulate digestion and absorption of nutrients. However, they also act as neurotransmitters within the central nervous system to control food intake. Peptide YY3-36 ( $P Y Y)$ is secreted predominantly from the distal gastrointestinal tract, which suppress appetite through sending signals to the hypothalamus [5]. Another brain-gut peptide is cholecystokinin (CCK), although which can not pass the blood brain barrier, can reduce feed intake though afferent vagal fibres to the caudal brainstem [6].

Pyridoxine (vitamin $\mathrm{B}_{6}$ ) is essential for absorption and metabolism of amino acids and the development of red blood cells [7]. Dietary pyridoxine can also alter the appetite. Low level of pyridoxine depressed appetite in chickens [8]. Baby pigs with pyridoxine deficiency have poor appetite and growth [9]. Dietary pyridoxine significantly attenuated the anorexia caused by heat stress in fingerlings [10]. Our previous study also showed that dietary pyridoxine increased significantly food intake in a dose-dependent manner ( 0 to $20 \mathrm{mg} / \mathrm{kg}$ ) in Rex rabbits [11]. But the effect of pyridoxine appetite-related peptides is still unknown. Pyridoxine is important for development and function of the nervous system. It acts as coenzymes for transaminases and controls the biosynthesis of neurotransmitters (e.g., gamma-aminobutyric acid, dopamine, and serotonin) [12]. Thus, we infer that the central and peripheric peptides may be regulated by the pyridoxine. In the present study, we investigated the effect of pyridoxine on the gene expression of food intake regulatory peptides in the hypothalamus and gastrointestinal tract of Rex rabbits. And the results will be useful to understand the progress of pyridoxine regulating energy homeostasis.

\section{Materials and Methods}

\subsection{Animals}

Three-month-old Rex rabbits were individually housed in self-made cages (60 $\mathrm{cm} \times 40 \mathrm{~cm} \times 40 \mathrm{~cm}$ ). Temperature and lighting were maintained according to commercial conditions. The diets were formulated according to the values to 
growing from de Blas and Mateos [13] and pelleted by pressure. The diameter of the pellets was $4 \mathrm{~mm}$. All rabbits received a diet containing $16.5 \%$ crude protein, $17 \%$ crude fiber and $10.5 \mathrm{MJ} / \mathrm{kg}$ of digestible energy.

\subsection{Experimental Protocol and Sample Collection}

At 90 days of age, 32 rabbits of similar body weight (1682 \pm 40 g) were divided into 2 groups, with 16 replicates per group and 1 rabbit per replicate. Rabbits were randomly subjected to 1 of the following 2 treatments: feeding basal diet (control; measured pyridoxine content was $4.51 \mathrm{mg} / \mathrm{kg}$ ) or feeding basal diet with additional $10 \mathrm{mg} / \mathrm{kg}$ pyridoxine supplementation (pyridoxine; measured pyridoxine content was $14.64 \mathrm{mg} / \mathrm{kg}$ ). The dose of pyridoxine was according to the study by Liu et al. [11], which found the pyridoxine addition of $10 \mathrm{mg} / \mathrm{kg}$ in basal diet could significantly increase significantly food intake in Rex rabbits. The experiment lasted for 8 weeks which included 1-week adaptation period and 7-week experimental period. At the end of the trial, rabbits were electrically stunned and killed [14]. The ARC and PVN samples were collected according to the method described in Prior et al. [15] and Mano-Otagiri et al. [16]. The samples of the whole intestinal tract were removed, and segments were taken from the midpoint of duodenum ( $5 \mathrm{~cm}$ from the pylorus), jejunum (50\% along the small intestine) and ileum (5 $\mathrm{cm}$ from the ileocecal junction) [17]. After being snap-frozen in liquid nitrogen, the tissue samples were stored at $-80^{\circ} \mathrm{C}$ until RNA extraction.

\subsection{RNA Isolation and Analysis}

Total RNA extraction and qRT-PCR were performed as described previously [18] [19]. Sequences of primers are shown in Table 1. The PCR data were analyzed with the $2^{-\triangle \triangle C T}$ method. The mRNA levels of target genes were normalized to glyceraldehyde 3-phosphate dehydrogenase $(G A P D H)$ mRNA $(\triangle \mathrm{CT})$. On the basis of the $\mathrm{Ct}$ values, GAPDH mRNA levels were stable across the 2 treatments in this study $(P>0.1)$.

\subsection{Statistical Analysis}

The data are presented as the means \pm SEM. Homogeneity of variances among the treatments was confirmed using Bartlett's test. All data were subjected to one-way ANOVA to test the main effect of the treatment. When the main effect of the treatment was significant, the differences between means were assessed by Duncan's multiple range analysis. $P<0.05$ was considered statistically significant.

\section{Results}

Although no significant difference was observed in $A g R P, N P Y, P O M C$ and $C A R T$ mRNA levels (Figure 1(a)) in ARC between 2 groups $(P>0.05)$, CRH and MC4R mRNA levels in PVN were significantly decreased after pyridoxine 
Table 1. Gene-specific primers used for the analysis of rabbit gene expression.

\begin{tabular}{|c|c|c|c|}
\hline Genes & GenBank accession No. & Primer sequence ( $\left.5^{\prime}-3^{\prime}\right)$ & Product size, bp \\
\hline$G A P D H$ & NM_001082253 & $\begin{array}{l}\text { F: TGCCACCCACTCCTCTACCTTCG } \\
\text { R: CCGGTGGTTTGAGGGCTCTTACT }\end{array}$ & 163 \\
\hline$N P Y$ & AB469827 & $\begin{array}{l}\text { F: CCTCATCACCAGGCAGAGAT } \\
\text { R: ATTTCGTTTCCCATCACCAC }\end{array}$ & 137 \\
\hline$A g R P$ & XM_002711615 & $\begin{array}{l}\text { F: GCTACTGCCGCTTCTTCAAC } \\
\text { R: CCATTCTTTATTGGCGTTCC }\end{array}$ & 133 \\
\hline POMC & XM_008254814 & $\begin{array}{l}\text { F: GCCTGGAAGATGCTGAGGT } \\
\text { R: CTCCTGACACTGGCTGCTCT }\end{array}$ & 102 \\
\hline$C A R T$ & XM_008274526 & $\begin{array}{l}\text { F: AGGAGCCAGGATTGGGAAG } \\
\text { R: CTGATGGAAGAGCGTGGAAG }\end{array}$ & 101 \\
\hline$P Y Y$ & XM_002719177 & $\begin{array}{l}\text { F: CTGAACCGCTACTACGCCTC } \\
\text { R: GTCTTCACCACGGGTAGGC }\end{array}$ & 166 \\
\hline $\mathrm{CRH}$ & NM_001199007 & $\begin{array}{l}\text { F: CATCTCCCTGGATCTCACCT } \\
\text { R: CCATCAGTTTCCTGTTGCTG }\end{array}$ & 101 \\
\hline$M C 4 R$ & HF970577 & $\begin{array}{l}\text { F: GGATACGGACGCACAGAGTT } \\
\text { R: AATGGAGGCAAGCAAGGAG }\end{array}$ & 82 \\
\hline$C C K$ & XM_002713069 & $\begin{array}{l}\text { F:AGCAACCTCCTGACCTTACG } \\
\text { R:GGCACTCACTGGACGATTTA }\end{array}$ & 140 \\
\hline
\end{tabular}

$G A P D H=$ glyceraldehyde 3-phosphate dehydrogenase; $N P Y=$ neuropeptide $\mathrm{Y} ; A g R P=$ agouti-related peptide; $P O M C=$ pro-opiomelanocortin; $C A R T=$ cocaine and amphetamine-regulated transcript; $P Y Y=$ Peptide YY3-36; $C R H=$ corticotropin releasing hormone; $M C 4 R=$ melanocortin receptor 4; $C C K=$ cholecystokinin.

treatment $(P<0.05$, Figure $1(\mathrm{~b}))$. By detecting the $P Y Y$ gene expression in different tissues of control rabbits, we found that the major expressed location is duodenum, and ARC had a lower expression of $P Y Y$ (Figure 2). As shown in Figure 3(a), dietary addition of pyridoxine significantly decreased the $P Y Y$ gene expression in duodenum $(P<0.05)$, but did not alter the $P Y Y$ gene expression in ARC, jejunum and ileum $(P>0.05)$. Besides, dietary pyridoxine treatment did not significantly alter on $C C K$ gene expression in all texted tissues $(P>0.05$, Figure 3(b)).

\section{Discussion}

Our previous study showed that pyridoxine could increase the food intake in rabbits [11], but the information in regards to that appetitive peptides response to this remains scarce. In the present experiment, the major appetite regulatory peptides in the hypothalamus (e.g., NPY, AgRP, POMC, CART, MCAR, CRH, $C C K$ and $P Y Y)$ and gastrointestinal tract $(C C K$ and $P Y Y)$ were detected after pyridoxine treatment in rabbits.

The balance between food intake and energy expenditure is regulated by the central nervous system, especially the hypothalamus. The dietary pyridoxine did not significantly affect the transcription of $N P Y / A g R P$ and POMC/CART neurons in the ARC in the present study. But Sanchez-Hernandez et al. [20] found 

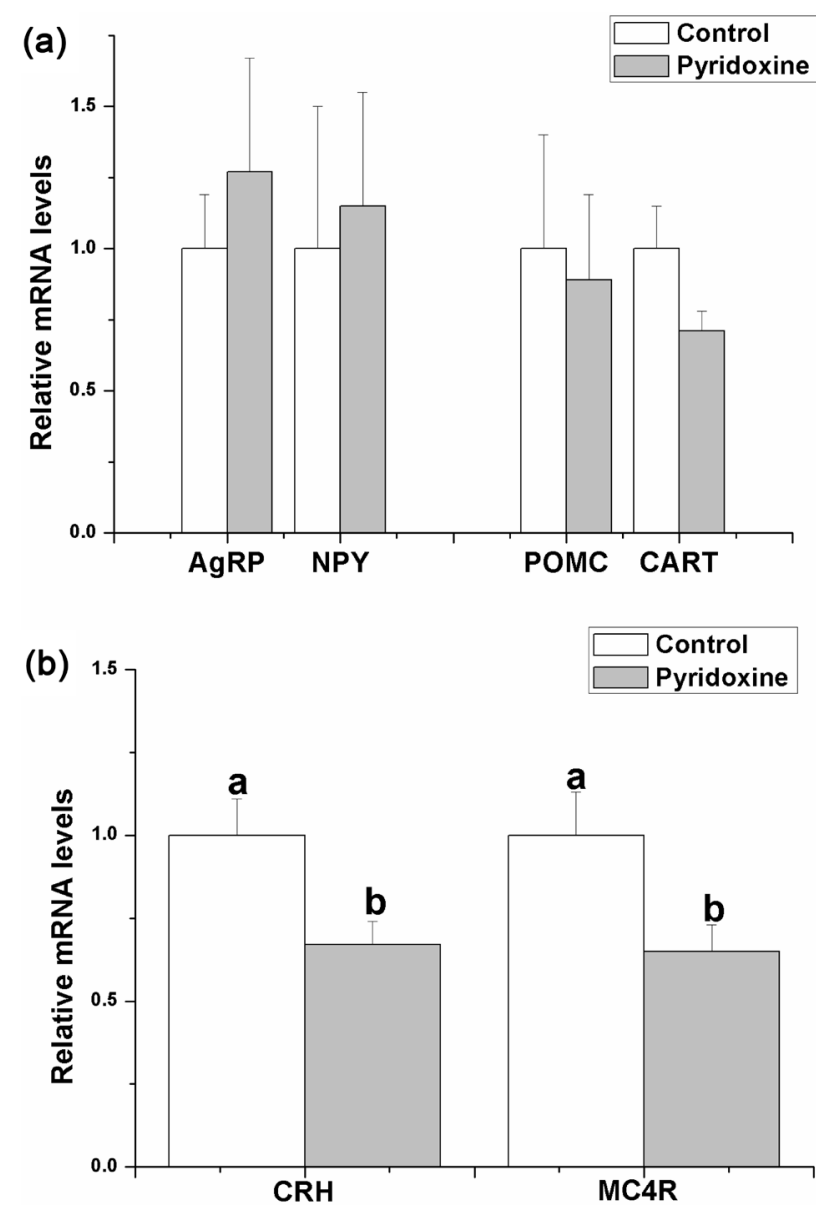

Figure 1. Effects of dietary pyridoxine on mRNA levels agouti-related peptide $(A g R P)$, neuropeptide Y $(N P Y)$, pro-opiomelanocortin (POMC) and cocaine and amphetamine-regulated transcript (CART) in ARC (a) and corticotropin releasing hormone $(C R H)$ and melanocortin receptor $4(M C 4 R)$ in PVN (b). Values are shown as the mean \pm SE $(n=8)$. a, b Means with different letters above bars are significantly different $(P<$ $0.05)$.

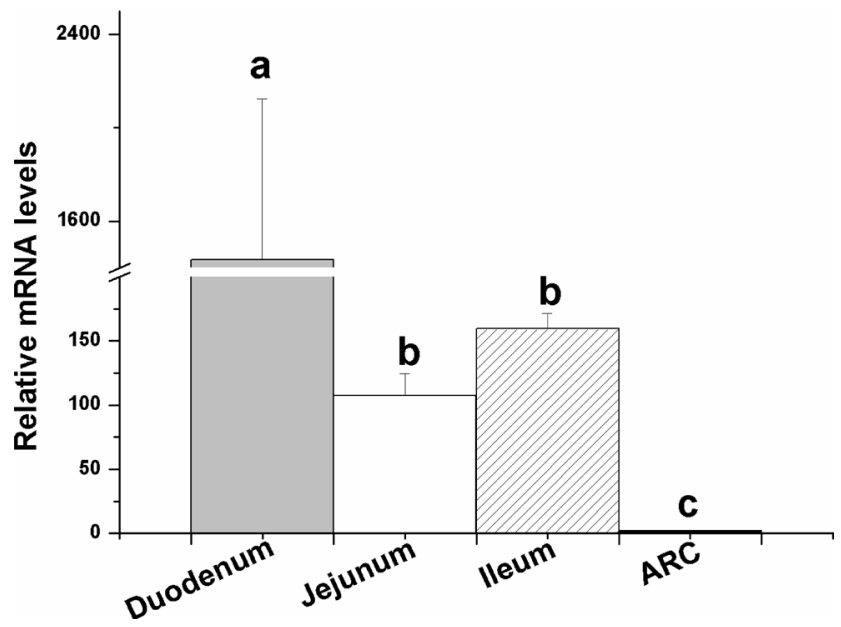

Figure 2. Peptide YY3-36 ( $P Y Y)$ gene expression in different tissue of control rabbits. Values are shown as the mean \pm SE $(n=8)$. a, b Means with different letters above bars are significantly different $(P<0.05)$. 

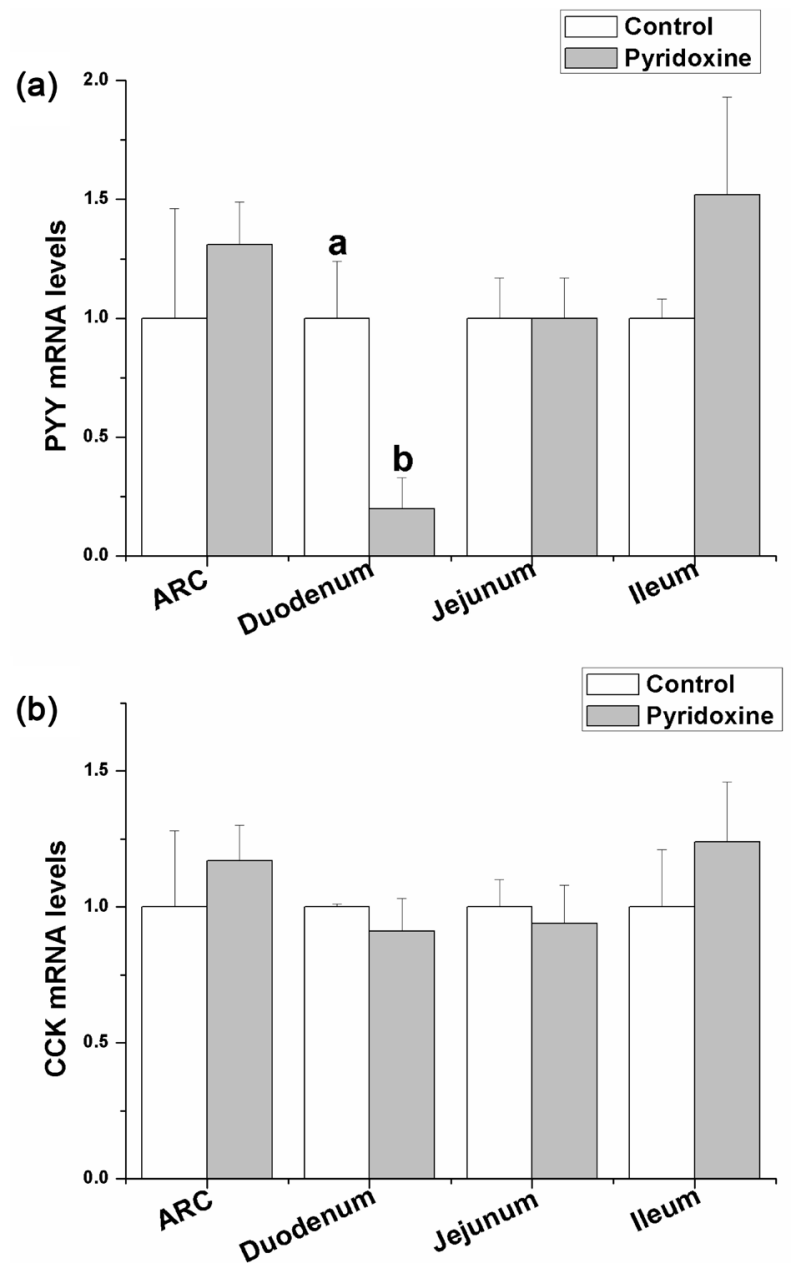

Figure 3. Effects of dietary pyridoxine on mRNA levels Peptide YY3-36 (PYY) (a) and cholecystokinin $(C C K)(\mathrm{b})$ in ARC, duodenum, jejunum and ileum. Values are shown as the mean \pm SE $(n=8)$. a, b Means with different letters above bars are significantly different $(P<0.05)$.

the multivitamins supplementation (10-fold vitamins $\mathrm{A}, \mathrm{D}, \mathrm{E}$, and $\mathrm{K}$ ) increased food intake via up-regulating ARC NPY levels in rats. The conflicting results may be caused by the different type of vitamins. And the regulating targets of water-soluble vitamins in appetite are different from that of the lipid-soluble vitamins.

The $M C 4 R$ are found in hypothalamic nuclei implicated in energy homeostasis, such as the ventromedial nucleus (VMH) and PVN [21]. Lacking the type-4 melanocortin receptor leads to hyperphagia and obesity in rodents [22]. And intracerebroventricular administration of a very low dose of melanocortin receptor agonist in adult rats reduces appetite [23]. In our study, dietary pyridoxine treatment significantly decreased the $M C 4 R$ gene expression in PVN, which suggests the $M C 4 R$ may be an important target in pyridoxine-caused hyperphagia. The finding is congruent with the results of other vitamin study in human, which have low intake of folate and vitamin $\mathrm{D}$, and have lower $M C 4 R$ expression [24]. 
Corticotropin-releasing hormone neurones are widely distributed in the mammalian central nervous system and can regulate ingestive behavior. Food intake is inhibited after central CRH injection [25]. The previous study found vitamin C supplementation decreased the synthesis of $C R H$ in adrenalectomized rats and normal rats. Our results showed that dietary pyridoxine down-regulates the $C R H$ mRNA levels in PVN, which implies that the $C R H$ neurones participate in the process that pyridoxine affects appetite. Besides, the suppressed $C R H$ mRNA levels by pyridoxine treatment may be associated with the $M C A R$. The $M C 4 R$ mRNA is high expressed in $C R H$ neurones, and activation of $M C 4 R$ expression can increase $C R H$ transcription [26].

Appetitive regulation is also involving peripheral control sites. The $C C K$ is a gut peptide that has long been established to act as a postprandial satiety signal [27]. Although $C C K$ mRNA levels were increased in the duodenum and jejunum in response to fatty acids, glucose and amino acids [28] [29], the CCK gene expression is not sensitive to the dietary pyridoxine in our study.

Peptide YY3-36 can increase food intake if administered directly into the cerebrospinal fluid. In contrast, peripherally administered PYY3-36 can reduce food intake [28]. The distribution of $P Y Y$ is species diversity. In rabbits, the duodenum has a higher expression than other small intestines. But $P Y Y$ is mainly expressed in ileum in mammals [30]. The $P Y Y$ can be stimulated by intraluminal nutrients, including glucose, bile salts, lipids, short-chain fatty acids and amino acids [31]. Our results showed that dietary pyridoxine decreased $P Y Y$ gene expression in duodenum, which is inconsistent with lipid-soluble vitamins-treated experiment that vitamin D increased circulating protein levels of $P Y Y$ [32]. Coll et al. [28] has proved that the anorexia effect of $P Y Y$ was initially thought to be mediated through the central melanocortin system. Thus, the suppressive $M C 4 R$ mRNA level of PVN in pyridoxine treatment may be related to decrease $P Y Y$ levels in peripheral tissue.

\section{Conclusion}

The present study showed that dietary pyridoxine decreased the mRNA levels of $M C A R$ and $C R H$ in PVN and $P Y Y$ in duodenum, but not alter the gene expression of $A g R P, N P Y, P O M C$ and $C A R T$ in ARC, $P Y Y$ in ARC, jejunum and ileum and $C C K$ in ARC, duodenum, jejunum and ileum. The results suggest that appetite-related genes of MC4R and $C R H$ in PVN and $P Y Y$ in duodenum may be involved in the pyridoxine-caused hyperphagia.

\section{Acknowledgements}

This work was supported by the Postdoctoral Science Foundation of China (2015M580601), Modern Agro-industry Technology Research system (CARS-44-B-1), Funds of Shandong "Double Tops" Program (2017, 2017003) and Youth Science and Technology Innovation Fund of Shandong Agricultural University (2015-2016). 


\section{Disclosure of Interest}

The authors declare that they have no conflicts of interest concerning this article.

\section{Ethics Statement}

All study procedures were approved by the Shandong Agricultural University Animal Care and Use Committee (SDAUA-2017-055) and were in accordance with the Guidelines for Experimental Animals established by the Ministry of Science and Technology (Beijing, China).

\section{References}

[1] Elias, C.F., Lee, C., Kelly, J., et al. (1998) Leptin Activates Hypothalamic CART Neurons Projecting to the Spinal Cord. Neuron, 21, 1375-1385.

https://doi.org/10.1016/S0896-6273(00)80656-X

[2] Kristensen, P., Judge, M.E., Thim, L., et al. (1998) Hypothalamic CART Is a New Anorectic Peptide Regulated by Leptin. Nature, 393, 72-76.

https://doi.org/10.1038/29993

[3] Broberger, C., Johansen, J., Johansson, C., Schalling, M. and Hokfelt, T. (1998) The Neuropeptide Y/Agouti Gene-Related Protein (AGRP) Brain Circuitry in Normal, Anorectic, and Monosodium Glutamate-Treated Mice. PNAS, 95, 15043-15048. https://doi.org/10.1073/pnas.95.25.15043

[4] Boswell, T. (2005) Regulation of Energy Balance in Birds by the Neuroendocrine Hypothalamus. Journal Poultry Science, 42, 161-168.

https://doi.org/10.2141/jpsa.42.161

[5] Vila G., Hopfgartner, J., Grimm, G., Baumgartner-Parzer, S.M., et al. (2015) Lactation and Appetite-Regulating Hormones: Increased Maternal Plasma Peptide YY Concentrations 3-6 Months Postpartum. British Journal of Nutrition, 24, 1-6. https://doi.org/10.1017/S0007114515002536

[6] Duraisamy, A.J., Bayen, S., et al. (2015) Changes in Ghrelin, CCK, GLP-1, and Peroxisome Proliferator-Activated Receptors in a Hypoxia-Induced Anorexia Rat Model. Endokrynologia Polska, 66, 334-341. https://doi.org/10.5603/EP.2015.0043

[7] Calderón-Guzmán, D., Hernández-Islas, J.L., Espitia-Vázquez, I., et al. (2004) Pyridoxine, Regardless of Serotonin Levels, Increases Production of 5-Hydroxytryptophan in Rat Brain. Archives of Medical Research, 35, 271-274. https://doi.org/10.1016/j.arcmed.2004.03.003

[8] Kratzer, F.H., Bird, F.H., Asmundson, V.S. and Lepkovsky, S. (1947) The Comparative Pyridoxine Requirements of Chicks and Turkey Poults. Poultry Science, 26, 453-456. https://doi.org/10.3382/ps.0260453

[9] Lehrer, W.P., Wiese, A.C., Moore, P.R. and Ensminger, M.E. (1951) Pyridoxine Deficiency in Baby Pigs. Journal of Animal Science, 10, 65-72.

https://doi.org/10.2527/jas1951.10165x

[10] Akhtar, M.S., Pal, A.K., Sahu, N.P., Alexander, C. and Meena, D.K. (2012) Effects of Dietary Pyridoxine on Growth and Physiological Responses of Labeo Rohita Fingerlings Reared in High Water Temperature. Israeli Journal of Aquaculture-Bamidgeh, 64, 1-6.

[11] Liu, G., Zhao, N., et al. (2015) Effects of Dietary Vitamin B6 Supplemental Level on Growth Performance and Vitamin B6 Metabolism of Growing Rex Rabbits. Chinese Journal of Animal Nutrition, 27, 2292-2299. 
[12] Rogers, K.S. and Mohan, C. (1994) Vitamin B6 Metabolism and Diabetes. Biochemical Medicine and Metabolic Biology, 52, 10-17. https://doi.org/10.1006/bmmb.1994.1027

[13] De Blas, J.C. and Mateos, G.G. (1998) Feed Formulation. In: de Blas, C. and Wiseman, J., Eds., The Nutrition of the Rbbit, Commonwealth Agricultural Bureau, Wallingfold.

[14] Lei, L., Hepeng, L., Xianlei, L., et al. (2013) Effects of Acute Heat Stress on Gene Expression of Brain-Gut Neuropeptides in Broiler Chickens. Journal of Animal Science, 91, 5194-5201. https://doi.org/10.2527/jas.2013-6538

[15] Prior, L.J., Eikelis, N., Armitage, J.A., et al. (2010) Exposure to a High-Fat Diet Alters Leptin Sensitivity and Elevates Renal Sympathetic Nerve Activity and Arterial Pressure in Rabbits. Hypertension, 55, 862-868. https://doi.org/10.1161/HYPERTENSIONAHA.109.141119

[16] Mano-Otagiri, A., Nemoto, T., Sekino, A., et al. (2006) Growth Hormone-Releasing Hormone (GHRH) Neurons in the Arcuate Nucleus (Arc) of the Hypothalamus Are Decreased in Transgenic Rats Whose Expression of Ghrelin Receptor Is Attenuated: Evidence That Ghrelin Receptor Is Involved in the Up-Regulation of GHRH Expression in the Arc. Endocrinology, 147, 4093-4103.

https://doi.org/10.1210/en.2005-1619

[17] Freeman, T.C., Bentsen, B.S., Thwaites, D.T. and Simmons, N.L. (1995) H+/ Di-tripeptide Transporter (PepT1) Expression in the Rabbit Intestine. Pflugers Archiv-European Journal of Physiology, 430, 394-400. https://doi.org/10.1007/BF00373915

[18] Liu, L., Song, Z., Jiao, H. and Lin, H. (2014) Glucocorticoids Increase NPY Gene Expression via Hypothalamic AMPK Signaling in Broiler Chicks. Endocrinology, 155, 2190-2198. https://doi.org/10.1210/en.2013-1632

[19] Wang, X.J., Xu, S.H., Liu, L., et al. (2017) Dietary Fat Alters the Response of Hypothalamic Neuropeptide Y to Subsequent Energy Intake in Broiler Chickens. Journal of Experimental Biology, 220, 607-614. https://doi.org/10.1242/jeb.143792

[20] Sanchez-Hernandez, D., Poon, A.N., Kubant, R., et al. (2015) A Gestational Diet High in Fat-Soluble Vitamins Alters Expression of Genes in Brain Pathways and Reduces Sucrose Preference, But Not Food Intake, in Wistar Male Rat Offspring. Applied Physiology Nutrition and Metabolism, 40, 424-431. https://doi.org/10.1139/apnm-2014-0480

[21] Harrold, J.A., Widdowson, P.S. and Williams, G. (1999) Altered Energy Balance Causes Selective Changes in Melanocortin-4 (MC4-R), But Not Melanocortin-3 (MC3-R), Receptors in Specific Hypothalamic Regions: Further Evidence That Activation of MC4-R Is a Physiological Inhibitor of Feeding. Diabetes, 48, 267-271. https://doi.org/10.2337/diabetes.48.2.267

[22] Fan, W., Boston, B.A., Kesterson, R.A., Hruby, V.J. and Cone, R.D. (1997) Role of Melanocortinergic Neurons in Feeding and the Agouti Obesity Syndrome. Nature, 385, 165-168. https://doi.org/10.1038/385165a0

[23] Olszewski, P.K., Bomberg, E.M., Grace, M.K. and Levine, A.S. (2007) Alpha-Melanocyte Stimulating Hormone and Ghrelin: Central Interaction in Feeding Control. Peptides, 28, 2084-2089. https://doi.org/10.1016/j.peptides.2007.07.017

[24] Garg, G., Kumar, J., McGuigan, F.E., et al. (2014) Variation in the MC4R Gene Is Associated with Bone Phenotypes in Elderly Swedish Women. PLoS One, 9, e88565. https://doi.org/10.1371/journal.pone.0088565

[25] Heinrichs, S.C. and Richard, D. (1999) The Role of Corticotropin-Releasing Factor 
and Urocortin in the Modulation of Ingestive Behavior. Neuropeptides, 33, 350-359. https://doi.org/10.1054/npep.1999.0047

[26] Lu, X.Y., Barsh, G.S., Akil, H. and Watson, S.J. (2003) Interaction between $\alpha$-Melanocyte-Stimulating Hormone and Corticotropin-Releasing Hormone in the Regulation of Feeding and Hypothalamo-Pituitary-Adrenal Responses. Journal of Neuroscience, 23, 7863-7872.

[27] Chaudhri, O., Small, C. and Bloom, S. (2006) Gastrointestinal Hormones Regulating Appetite. Philos. Philosophical Transactions of the Royal Society of London Series B-Biological Sciences, 361, 1187-1209. https://doi.org/10.1098/rstb.2006.1856

[28] Coll, A.P., Farooqi, I.S. and O’Rahilly, S. (2007) The Hormonal Control of Food Intake. Cell, 129, 251-262. https://doi.org/10.1016/j.cell.2007.04.001

[29] Rushakoff, R.A., Goldfine, I.D., Beccaria, L.J., et al. (1993) Reduced Postprandial Cholecystokinin (CCK) Secretion in Patients with Noninsulin-Dependent Diabetes Mellitus: Evidence for a Role for CCK in Regulating Postprandial Hyperglycemia. Journal of Clinical Endocrinology and Metabolism, 76, 489-493.

[30] Adrian, T.E., Ferri, G.L., Bacarese-Hamilton, A.J., et al. (1985) Human Distribution and Release of a Putative New Gut Hormone, Peptide YY. Gastroenterology, 89, 1070-1077. https://doi.org/10.1016/0016-5085(85)90211-2

[31] Ballantyne, G.H. (2006) Peptide YY(1-36) and Peptide YY(3-36): Part I. Distribution, Release and Actions. Obesity Surgery, 16, 651-658. https://doi.org/10.1381/096089206776944959

[32] Choi, M., Ozeki, J., Hashizume, M., et al. (2012) Vitamin D Receptor Activation Induces Peptide YY Transcription in Pancreatic Islets. Endocrinology, 153, 5188-5199. https://doi.org/10.1210/en.2012-1396

\section{Submit or recommend next manuscript to SCIRP and we will provide best} service for you:

Accepting pre-submission inquiries through Email, Facebook, LinkedIn, Twitter, etc. A wide selection of journals (inclusive of 9 subjects, more than 200 journals)

Providing 24-hour high-quality service

User-friendly online submission system

Fair and swift peer-review system

Efficient typesetting and proofreading procedure

Display of the result of downloads and visits, as well as the number of cited articles

Maximum dissemination of your research work

Submit your manuscript at: http://papersubmission.scirp.org/

Or contact abb@scirp.org 